\title{
Assessment of risk factors associated with spread of tuberculosis in Gujrat city Pakistan
}

\author{
Pakistan'ın Gujrat kentinde tüberkülozun yayılması ile ilişkili risk faktörlerinin \\ değerlendirilmesi
}

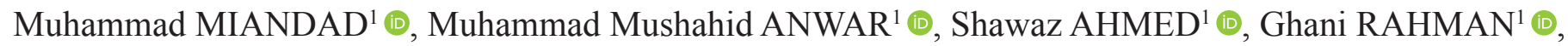 \\ Mehtab Ahmed KHAN ${ }^{1}$ (D)
}

${ }^{1}$ University of Gujrat, Department of Geography, Gujrat, Pakistan

ORCID: M.M. 0000-0002-4339-8181; M.M.A. 0000-0002-7370-8101; S.A.0000-0002-4019-4079; G.R. 0000-0002-5091-2337; M.A.K. 0000-0001-9575-382X

\begin{abstract}
Like other cities of Pakistan, Gujrat is also facing problems to eradicate tuberculosis. The current paper is an effort to highlight the risk factors which are responsible for the spread of tuberculosis in the urban areas of Gujrat city. Tuberculosis data were collected from the District Health Officer, the National Tuberculosis Control Program and the Aziz Bhatti Shaheed Hospital, Gujrat. Data were analyzed temporally from 2013 to 2016, which showed the escalation of TB cases. Questionnaire survey-based data were analyzed in Principal Component Analysis using SPSS software. Three factors were extracted from the PCA. Factor 1 revealed the highest correlation of 37 variables. On the basis of the highest loadings of variables, Factor I was named as the socio-ecological and demographic status. It is evident from Factor I that tuberculosis has the highest relation with social, ecological and demographic factors in the study area. Factor II is named as the socio-economic and ecological factors, and indicates the relationship of social, economic and ecological factors of the disease. There is an urgent need to evaluate the vulnerable population of urban areas on a priority basis, i.e Moinuddin pur, Kanjah, Adhowal, and Madina UCs. Unplanned urbanization, poor garbage disposal, lack of recreational facilities, poverty, and poor management of the city, accessibility to health facilities, diet and diagnosis are favorable factors for disease transmission.
\end{abstract}

Keywords: Tuberculosis, risk factors, health, Gujrat

\section{öz}

Pakistan'ın diğer şehirleri gibi Gujrat da tüberkülozu ortadan kaldırma çabası içerisindedir. Bu çalışma Gujrat'ın şehir bölgelerinde tüberkülozun yayılmasına neden olan faktörleri ortaya koymayı amaçlamıştır. Tüberküloza ait veriler bölge sağlık görevlileri, Ulusal Tüberküloz Kontrol Programı ve Aziz Bhatti Shaheed Hastanesi'nden toplanmıştır. 2013 - 2016 aralığına ait veriler tüberkülozda artış olduğunu ortaya koymuştur. Saha anketlerinden toplanan verilere SPSS yazılımıyla temel bileşen analizi uygulanmıştır. Bu analizden sonucunda tüberkülozu arttıran 3 faktör saptanmıştır. 37 değişken arasındaki en yüksek korelasyonu gösteren ve tüberkülozun yayılmasında en yüksek paya sahip olan faktör sosyoekolojik ve demografik özelliklerdir. İkinci sırada yer alan faktör sosyoekonomik faktördür. Moinuddin pur, Kanjah, Adhowal ve Madina acil eylem gerektiren, hassas nüfusun çoğunlukta olduğu bölgelerdir. Plansız şehirleşme, yetersiz atık yönetimi, rekreasyonel birimlerin azlığı, yoksulluk, kötü şehir yönetimi, sağlık birimlerine erişimdeki zorluklar hastalığın yayılmasına neden olan önemli etmenlerdir.

Anahtar kelimeler: Tüberküloz, risk faktörleri, sağlık, Gujrat

Submitted/Başvuru: 09.08.2019 • Revision Requested/Revizyon Talebi: 10.10.2019 • Last Revision Received/Son Revizyon: 20.10.2019 • Accepted/Kabul: 21.11.2019 • Published Online/Online Yayın: 27.12.2019 


\section{EXTENDED ABSTRACT}

Tuberculosis is a highly contagious disease that has been killing the human being since 5000 BC. Pakistan is a developing country facing innumerable problems to eliminate the disease. Like the other cities of Pakistan, Gujrat is also facing problems to eradicate the disease. The current paper is an effort to highlight the risk factors which are responsible for the spread of tuberculosis in the urban areas of Gujrat city. Tuberculosis data were collected from the District Health Officer, the National Tuberculosis Control Program and the Aziz Bhatti Shaheed Hospital Gujrat. The data were analyzed temporally from 2013 to 2016, which showed the escalation of TB cases. A questionnaire survey was conducted to assess the risk factors of tuberculosis. Data were analyzed in SPSS using Principal Component Analysis with Kaiser Normalization and supported by frequency graphs. Questionnaire survey-based data were analyzed in Principal Component Analysis (PCA) using SPSS software. Three factors were extracted from PCA. Factor 1 revealed the highest correlation of 37 variables. On the basis of the highest loadings of variables, Factor I is named as socio-ecological and demographic status. It is evident from Factor I that tuberculosis has the highest relation with social, ecological and demographic factors in the study area. Factor II, named as socio-economic and ecological factors, indicates the relationship of social, economic and ecological factors which were responsible for the spread of tuberculosis.

Tuberculosis has a correlation with a number of indicators that include social, ecological and demographic indicators. As it is evident from results and discussions, the socioeconomic, ecological and demographic indicators are responsible for the spread of TB in the study area. There is an urgent need to evaluate the vulnerable population of urban areas on a priority basis i.e. Moinuddin pur, Kanjah, Adhowal and Madina UCs. Unplanned urbanization, poor garbage disposal, lack of recreational facilities, poor management of urban green spaces, rapid urban sprawl, and accessibility to health facilities, diet and diagnosis are favorable factors for disease transmission. Socioeconomic and ecological factors can be improved by the combined effort of health planners and the urban development authorities. 


\section{INTRODUCTION}

According to the World Health Organization, the second most common cause of death in the world through infectious diseases, TB, kills about 1.3 million people annually. Every year, about 10.0 million new TB cases occur, $95 \%$ of which are found in developing countries. Approximately 16-20 million people in the world are infected with TB, while $80 \%$ of the cases occur amongst people in the age group 15-59 years i.e. the most economically productive group. This exerts a tremendous burden on the economies of the countries affected by it, as well as for patients(World Health Organization, 2019). Twenty-two countries, considered as the High Burden Countries (HBCs), reported $80 \%$ of the total TB disease burden. The highest occurrence rate is in Africa, while the highest number of cases is found in the heavily populated countries of Asia e.g. India, China, Indonesia, Philippines, Pakistan, and Bangladesh. Altogether, they account for more than half of the global TB burden. Pakistan ranks $5^{\text {th }}$ among the high TB burden countries, the incidence is 231 per 100000 population with 510000 new cases annually (Middelkoop, Bekker, Morrow, Lee, \& Wood, 2014; Tiberi et al., 2018; World Health Organization, 2019).

Health care officials and researchers are cognizant of the significance of the geographical location of diseases and their relationship with environment, water contamination, ecology, and host-related factors. Linking of spatially varying risk factors to the location of the occurrence of diseases is also of current interest (Imran, M., Jahanzaib, S., \& Ashraf, A.” Using geographical information systems to assess groundwater contamination from arsenic and related diseases based on survey data in Lahore, Pakistan". Arabian Journal of Geosciences, 10(20), 450, 17 October, 2017 doi.org/10.1007/s12517-017-3212-9). One-third of the world's population is infected with tuberculosis. Every second, one person in the world is infected with TB infection i.e. every year $01 \%$ of the world's population is infected with TB. All infections with Mycobacterium tuberculosis do not cause the disease (De Muynck, Siddiqi, Ghaffar, \& Sadiq, 2001; World Health Organization, 2010).

Increased susceptibility to diseases, especially TB, is associated with overcrowding along with poor housing quality which are unhealthy, being linked with poverty and specific racial groups. Due to poor air quality within homes, overcrowding and inadequate/improper ventilation, presence of mold, smoke and fumes contribute significantly to poor respiratory health, and have been related with the increase /outcome of tuberculosis (Wanyeki et al., 2006; Rees, Murray, Nelson, \& Sonnenberg, 2010; Keall et al., 2012).
Patients suffering from acute pulmonary TB spread the bacteria through the air by coughing, sneezing or speaking. M. tuberculosis survives in the air for several hours, depending on environmental conditions. Very few bacteria inhaled by any person are capable of infecting them. Latent TB is the condition when people carry the bacteria but do not develop tuberculosis. The carrier, however, becomes sick when his immune system is weakened (e.g. by some other disease). Around 05 to $10 \%$ of the infected persons develop active TB during their lifetime, the majority of them within the first two years of contracting the infection, subsequently become carriers of the infection (Turkington \& Ashby, 2007).

Shetty et al., 2006 assessed sociodemographic risk factors pertaining to tuberculosis in South India, based on data collected through a questionnaire survey pertaining to religion, marital status, household size, occupation, employment, number of rooms in houses, separate kitchens, use of biomass fuels, etc. The study revealed an association of TB with low education levels, nonavailability of separate kitchens, urbanization and negativity of economic conditions, particularly in Bangalore (Shetty, Shemko, Vaz, \& D’souza, 2006).

Farchi et al. (2008) collected data from different sources pertaining to incidence, prevalence, and hospitalization of patients in Italy between the years 1997 and 2003. They found that the incidence of tuberculosis declined from 15 to 11 per 100000 during that period. However, it was found that the number of cases among foreign immigrants also increased significantly. Hence, it was suggested to especially focus on immigrants for the control of tuberculosis (Farchi, Mantovani, Borgia, \& Giorgi Rossi, 2008).

An integrated intervention study conducted by Fatima et al., 2014 in four districts of the Sindh province (Pakistan) was a project-based study to detect the undiagnosed cases of TB in urban slums. They concluded that active case detection could produce better results by engaging private providers and chest camps.

According to the WHO, the incidence of tuberculosis in Pakistan is $231 / 100,000$, and prevalence is $350 / 100000$. Due to TB, Pakistan is facing $5.1 \%$ of the total national disease burden. The impact of $\mathrm{TB}$ on the socioeconomic condition is significant. It is one of the most widespread, and regrettably, one of the most ignored, health areas. It is the responsibility of NTP to develop national framing policies and guidelines, and create funds for the achievement of TB control procedures at the local, district and provincial levels. (Byers, 2016) The Directly Observed Treatment Short-course is the part of primary health care adopted as the National Plan in 2000, and broadened to cover all public health services (Qadeer et al., 2016). 
The case detection and the treatment outcomes were achieved by the STOP TB partnership i.e., $70 \%$ and $85 \%$ respectively, which was the global target. There are still many issues regarding TB Control, in spite of rapid expansion and a combination of TB care. In most of the underdeveloped countries, treatment completion rate has been very poor (Cameron et al., 2018). It is posed as a risk not only for patients but for the entire population as well, due to which prior disease eradication policies failed and the new treatment DOTS had to be adopted (Khan et al., 2007; Obermeyer, Abbott-Klafter, \& Murray, 2008).

The long duration of treatment of the disease, which entails prolonged absenteeism from the job along with lack of support during the interim period, has a heavy toll on the poor. They find it extremely difficult to cope with the situation, as a result of which, they either default from treatment or resort to other relatively affordable and available treatments like purchasing drugs over the counter or availing other services over short periods. The health system suffers from lack of initiative due to the absence of committed monitoring and support, which in turn leads to short supplies of drugs, hence the disinterest of experts (Hossain et al., 2012). High rates of tuberculosis have been known to be associated with sociodemographic variables like poverty, overcrowding, and migration, especially in backward or developing parts of the world (Mangtani, Jolley, Watson, \& Rodrigues, 1995).

Khan et al. (2007) underlined important factors that were found useful and effective for DOTS in Pakistan, i.e. cost to patients (both in time and money), access to services, and distance of health center from patients' homes, and chaperones for women patients. Service providers of the TB patients were notified to be attentive to the fact that several potential causes were not related to patients' responsibilities. In 1993, TB was confirmed as a global emergency by WHO(Khan, Nazir, Tahir, Khan, Abbas, \& Younus, 2007). Gujrat recorded more than 4000 new cases of TB in the year 2016, while a significant number of cases are missing (Zumla et al., 2015).

There is an extreme need not only for long term uninterrupted treatment of TB, but for regular monitoring of patients to ensure compliance to treatment already initiated. Under the prevailing disappointing conditions regarding the management of $\mathrm{TB}$, a multifaceted approach must be adopted. Ensuring correct prescriptions written by hospital doctors, since they are doctors of teaching hospitals, and for anti-TB therapy, should it be ascertained as Private Providers (PPs) follow them. In addition, although new diagnostic tests are available, the conventional method of sputum smear and culture should not be abandoned, as the novel methods are still research tools even in the advanced world or HDCs.
NTP should be strengthened by continuing medical education in the treatment of TB at both undergraduate and postgraduate levels. National TB guidelines should be included in the medical school curriculum. Implementation and pursuance of DOTS are necessary. Clear information on the treatment and prevention of TB should be disseminated via simple booklets. Electronic and print media should be revamped, public education regarding NTP with reference to the treatment of TB and where to receive it, etc. should be inculcated (Miandad, Nawaz-ul-Huda, Burke, Hamza, \& Azam, 2016).

By the end of the nineteenth century, the contribution of geographical factors to pathological complexes was established. Thus, TB is also closely related to geographical /environmental factors, i.e., geogens. According to the WHO, poverty, and overcrowding, i.e., socioeconomic factors are the main causes of TB (World Health Organization, 2006)

Gujrat has been facing a plethora of problems in all aspects of life, but health has remained the burning issue of all times. Gujrat is characterized by a myriad of geographical and environmental features, which are responsible for the rapid spread of the disease. Gujrat. with its estimated 4000 new cases of TB every year. and with its high degree of congestion and incessant immigration, needs a geographical study for the evaluation of various risk factors related to TB.

Tuberculosis, a highly contagious disease, has a strong correlation with socioeconomic cum demographic and ecological factors. Identification of risk factors and its spatial intensity is necessary in order to provide suggestions to control and eradicate the causal factors from the point of view of medical geography.

Tuberculosis is a contagious disease. It is one of the major public health problems in developing countries, including Pakistan and some highly-congested cities like Gujrat.

GIS is a powerful tool to show the epidemiology of TB in any area. TB is a contagious disease, which is an important health issue in many developing countries like Pakistan. Therefore, it was thought pertinent to research and provide guidelines for the improvement of health conditions of the people of Gujrat, for preventing the disease as well as trying to eradicate it. Gattrell and Loytonen (1998)(Gatrell \& Loytonen, 1998) stated that largescale infection determinants' comprehension and reliable paraphernalia for the identification of populace for mass treatment has been possible in the past two decades through the use of Geographic Information Science. 


\section{S T U D Y A E A}

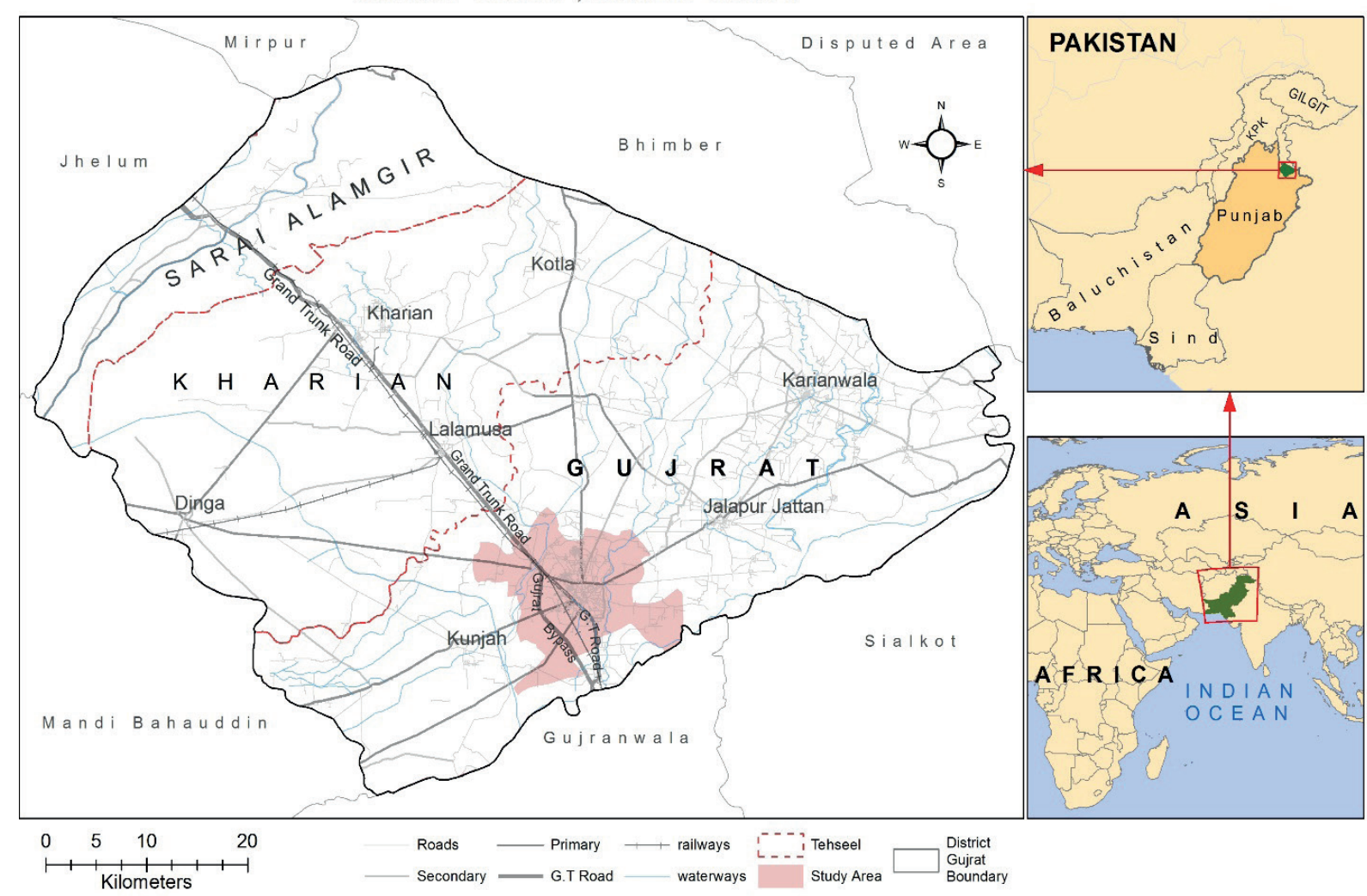

Figure 1: Study area-Gujrat City.

The current study identifies the causal factors of tuberculosis in the city. This will be helpful for the national TB control programs, NGOs, private hospitals and medical geographers who are working to minimize and eradicate this ailment from society.

\section{MATERIALS AND METHODS}

Data regarding the current research study were collected from different departments, which include the Population census organization, the District Health officer, the Aziz Bhatti Shaheed Hospital and the National TB Control Program, which is acknowledged accordingly.

A questionnaire survey was conducted for the collection of data regarding risk factors of tuberculosis. According to Tavakol M and Sandar J, 2014, (Tavakol \& Sandars, 2014) and Silverman (2010)(Silverman, 2013), the primary survey data allow investigators to achieve a gorgeous, comprehensive and varied data set in an easy situation. Both types close and open-ended questionnaires have been used in the study. Open-ended questions permit a systematic investigation of understandings, approaches or feelings that close-ended inquiries could never achieve (Cresswell \& Sheikh, 2013; Creswell \& Creswell, 2017).
However, both types of questions were included in the present research to investigate the risk factors of the disease. Data have been given to contenders about the ethical issues and objectives of the present research. Choice has been given to participant for taking part in the survey or not, with proper assurance for privacy.

Tuberculosis and population data have been collected from different departments, e.g. Government Publications, Government Departments, Hospitals, BMUs, District Health Officer Gujrat, etc., such as Tuberculosis data were collected from the Aziz Bhatti Shaheed Hospital, the National Tuberculosis Control Program, Pakistan, as well as from the DHO, Gujrat. Data of Population were collected from the Population Census Organization of Pakistan.

Published articles, workshops, conferences, books, and websites were also used for relevant information.

The questionnaire data was compiled in Excel and SPSS software. Important variables related to the risk factor and disease ecology were formulated accordingly. 
Table 1. Variables and their measurement scale

\begin{tabular}{lll}
\hline Variables & Description & Measurement Scale \\
\hline Gender & Check gender of respondent & Dichotomous \\
Age & No. of years since birth & Categorical \\
Education & Highest academic degree & Categorical \\
Income & Total income of household & Categorical \\
Smoking & Tobacco smoking (cigarette and piped) & Dichotomous \\
Family status & People living with their grandparents & Dichotomous \\
House type & Living entity & Dichotomous \\
Employment & Receiving monthly salary & Dichotomous \\
Profession & Nature of earning source & Categorical \\
Children & No. of children of respondent & Categorical \\
Rooms & No. of rooms in the household & Categorical \\
Garbage & Kitchen and other litter disposal & Dichotomous \\
Residential area & Place of permanent living & Dichotomous \\
Food & Calorie intake and quality & Five-point likert \\
Diagnosis & Test for disease confirmation & Five-point likert \\
Awareness & Information regarding tuberculosis & Five-point likert \\
Distance & Distance from health care facility & Categorical \\
Green Space & Open green space for recreational activities & Categorical \\
Drinking Water & Plain water for drinking & Dichotomous \\
Disease vaccination & Immunization during childhood & Dichotomous \\
Disease history & Presence of patients in family & Dichotomous \\
Ethnic group & Language of respondent & Categorical \\
\hline
\end{tabular}

Irrelevant variables were either excluded or used as supportive variables. In order to extract the causative factors for the analysis of the questionnaire, Factor Analysis was performed using Principal Component Analysis. The factor that possesses disease relevancy was analyzed using Principal Component Analysis (PCA). In epidemiological studies, although multiple statistical methods for data analysis are used, in the current study PCA was used due to its exclusive features. (Dunteman, 1989; Mankin, 2003).

Williams et al, (2010)(Williams, Onsman, \& Brown, 2010) stated that with the advancement of Information Technology, factor analysis and multivariate methods became popular even among researchers.

The questionnaire survey was conducted, and 300 questionnaires were completed from the study area. There were 8 Union Councils in the urban areas of Gujrat city, and questionnaires were filled using a randomized sampling method from the residents (patients) of each union council.

Figure 1 shows the study area, i.e., urban areas of Gujrat city, while Figure 2 shows the distribution of patients and their location. Figure 3 shows the temporal distribution of TB cases during Quarter 12013 to Quarter 4 2016. It is evident from Figure 3 that female cases were higher than males in almost all quarters of these years.

Tuberculosis has a correlation with geo-demographic factors, which includes within its purview socioeconomic, demographic,

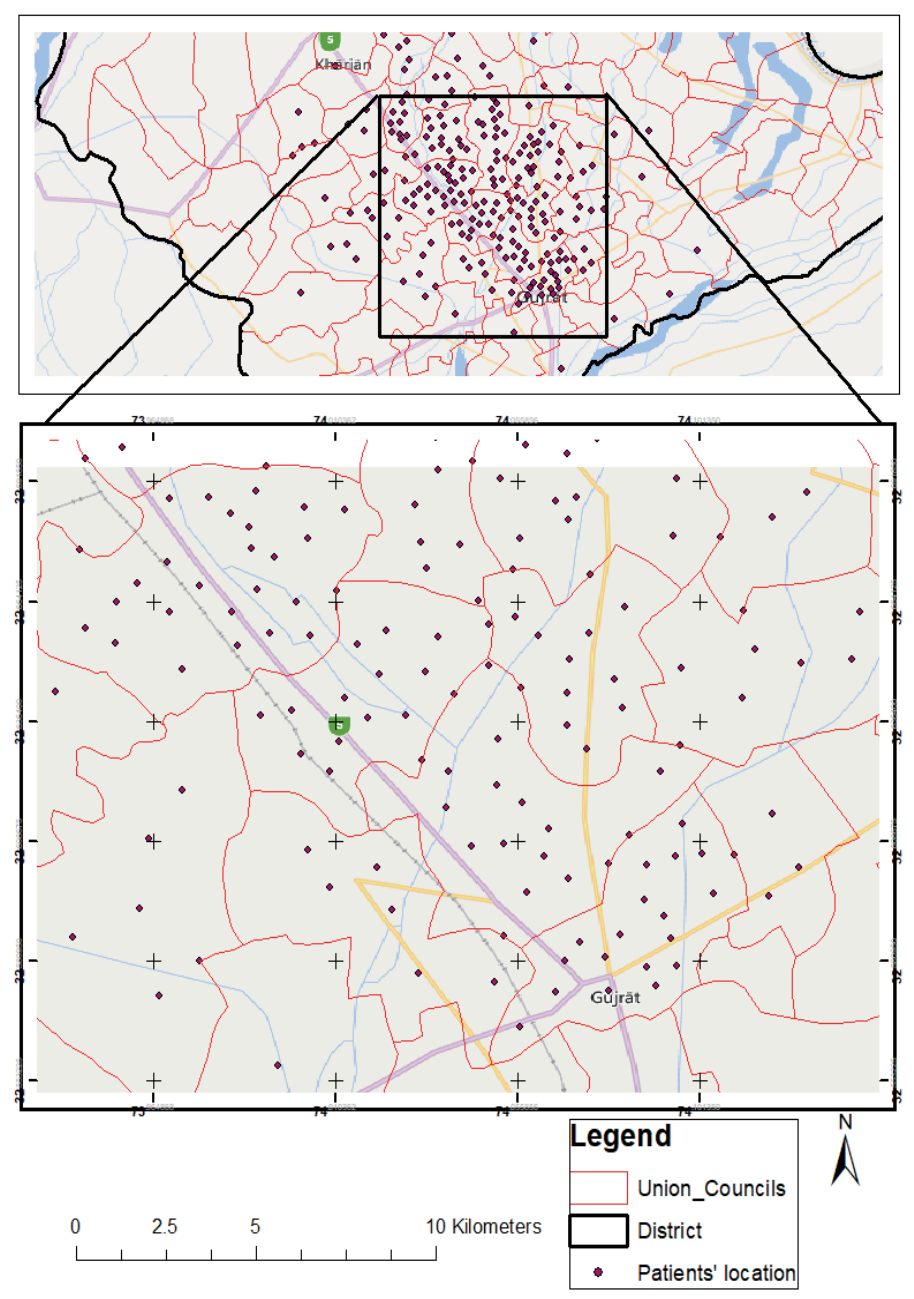

Figure 2: Patients' Location within the study area. 


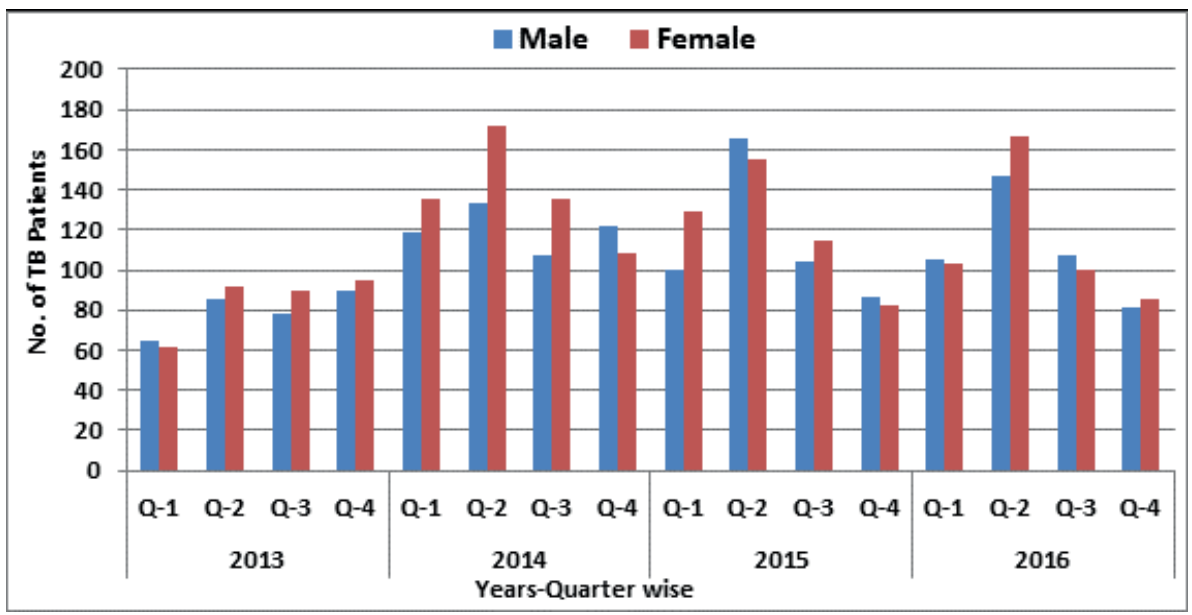

Figure 3: Distribution of TB cases Quarterly from 2013 to 2016 (Data source: NTP and Aziz Bhatti Shaheed Hospital).

environmental and ecological aspects. In order to identify the risk factors for the spread of TB, a questionnaire survey was conducted in the union councils of Gujrat. Data were used according to the age structure of patients in the study area. Based on the principal component analysis (PCA), factor analysis has been employed for the 50 variables considered relevant for the various aspects. The investigation extends cogent arguments for risk factors of tuberculosis in terms of ecology, social, demographic and economic issues.

\section{FACTOR STRUCTURE}

One of the easiest techniques for the multivariate study is factor analysis(Williams, Onsman, \& Brown, 2010; Miandad, Burke, Nawaz-ul-Huda, Ghazi, \& Azam, 2015). The procedure evidently examines the variables that may be responsible for the phenomena under observation. It reduces a huge array of data into factors (Pearson, 1901). Being concerned with explaining correlations among original variables, it provides help in developing a cause and effect model regarding the quality of life of patients. (Hawthorne, Richardson, \& Osborne, 1999).

Employing the PCA technique, all variables selected for the study were factorized on the basis of age groups for analytical purposes. Three factors have emerged prominently with reference to the spread of tuberculosis in the study area. The correlation matrix for all the 47 variables is shown in Annexure A. The most significant positive and negative correlations from highest to moderate percentages, i.e., 0.9 to 0.5 , which have emerged pertaining to the TB patients in the study area, have been taken under consideration for analysis.

Table 2 explains total variance extracted by PCA technique.
Annexure A shows three factors and their variance that has been extracted from the selected variables.

The data pertaining to the 47 variables explain $91.88 \%$ of the total variance. The first Factor explains $53.11 \%$ of the variance, with more than $50 \%$ of the variables showing a strong correlation, while Factors II and III explain 29.56 and $9.19 \%$, respectively, of the variance.

- Extraction Method: Principal Component Analysis

- Rotation Method: Varimax with Kaiser Normalization

- A Rotation converged in 04 iterations.

Table 2: Extraction Method: Principal Component Analysis.

\begin{tabular}{llll}
\hline \multirow{2}{*}{ Component } & \multicolumn{3}{l}{ Rotation Sums of Squared Loadings } \\
\cline { 2 - 4 } & Total & \% of Variance & Cumulative \% \\
\hline 1 & 28.153 & 53.118 & 53.118 \\
2 & 15.671 & 29.568 & 82.686 \\
3 & 4.874 & 9.196 & 91.882 \\
\hline
\end{tabular}

Details of variables of the Rotated Component Matrix have been given in Annexure A.

\section{RESULTS AND DISCUSSION}

On the basis of PCA loadings the variables are divided into 3 significant factors:

\subsection{Factor I - socio-ecological cum demographic status}

The first factor explains $53.11 \%$ of the total variance with reference to all the designated variables (Table 2). The characteristics of the factor are clearly recognizable by very high positive loadings (more than 0.500 ) for 41 variables. An insight into the variables for Factor I depicts that socio-ecological cum demographic features related to urban expansion seem to be 
categorically responsible for the spread of TB in Gujrat, especially among residents with a low quality of life. Unstable social life, especially due to low, restricted incomes, has emerged as considerable among the TB patients. All variables recording positive (1.00 to 0.500$)$ and negative (-1.00 to -.500$)$ loadings reveal that they behave in a certain dependable approach. Positive loadings have been recorded for all features that are responsible for the incidence and spread of TB, while the negative loadings for nutrition consumed twice a day, reveals the impact of diet on health. It clarifies the important role of food in curtailing, as well as in fighting the disease. (Lienhardt et al., 2005) conducted study in three African countries, and highlighted the risk factors as marital status, family history, smoking, and crowding. A study conducted by (Miandad, Burke, Ul-Huda, \& Azam, 2015) in Karachi, Pakistan assessed risk factors which include poverty, low income, smoking, malnutrition, overcrowding, and diagnosis.

The highest positive loadings of the variables have arisen for the respondents who eat meat once in a month $(0.973)$, no tree in house (0.971), laborer patients (0.96), distance of hospital from patients' house 3-6 km (0.96), distance of public park from patients' house (0.95), eat meat once week (0.94), unmarried (0.94) enrolled patients (0.92), distance from greenery more than $10 \mathrm{~km}(0.91)$, unemployed (0.90), domestic food user (0.89), eat meat twice a month (0.88), patients' monthly income between 10000-15000 PKR (0.87), family size of more than 7 persons (0.86), Punjabi speaking patients $(0.85)$, persons per room more than $3(0.847)$, distance from greenery $(0.84$ female patients $(0.809)$, male patients (0.807), graduate patients (0.797), monthly income 1600-20000 (0.796), patients having intermediate level education (0.795).

Kashmiri speaking (0.793), patients having family history of TB (0.77), distance from hospital 6-10 km (0.776), patients having government job (0.74), Urdu speaking patients (0.72), patients living primary education $(0.71)$, distance from park more than 10 $\mathrm{km}(0.694)$, distance from greenery $5 \mathrm{~km}(0.690)$, eat meat twice week (0.683), distance from park $5 \mathrm{~km}(0.682)$, family patient treated (0.67), distance from hospital more than $10 \mathrm{~km}(0.66)$,family size more than 4 persons (0.57) Food from bazaar (0.52) and private job (0.50) have emerged as most responsible for the incidence and spread of TB along without having any significant negative loading.

Epidemiological triad describes the interaction among pathogen, host and environmental (ecological) factors, which are important leading factors for the spread of infectious diseases, especially tuberculosis. A study conducted in Congo using demographic data, which reveals that HIV and social factors are the risk factor.
(Eisenberg et al., 2007) conducted a study in the USA to evaluate the environmental risk factor for infectious diseases.

A polluted environment in close proximity to homes is responsible for the spread of infectious diseases. Indicators associated with tuberculosis are shown in Table 1 (Annexure A) Correlation matrix has emerged variables regarding the spread of TB, Factor I (i.e. Socio-ecological and demographic indicator) highpoints the major sources. All positive loadings point towards a low standard of living under urbanized environments in a third world country. All the associated variables have a relation both to social, ecological and demographic parameters of urban living responsible for the spread of the tuberculosis infection.

Table 2 and Annexure A portray a plausible relationship among the variables responsible for the high loading of variables in Factor I. Socio-ecological and demographic conditions have played a vital role in the expansion of infectious diseases, especially tuberculosis, in the study area. Out of the total questionnaire sample of $300 \mathrm{~TB}$ patients (respondents), the incidence of the disease was $01.00 \%$ higher among females than males. The significance of urbanization on the total life and economy of any country's progress is not only dependent on the increase of urban population concurrent to large scale immigration, especially from rural areas, but also by a myriad of social, economic, environmental and ecological problems. Irrespective of developed or developing countries, massive urbanization, and high population densities not only create socioeconomic problems but environmental and ecological deterioration which further leads to health problems. (Antrop \& Van Eetvelde, 2000; Pauleit, Ennos, \& Golding, 2005; Deneulin \& Alkire, 2009; Antczak, 2016; Lopez-Carr \& Ervin, 2017).

In third world countries, various researches have proven that corrupt city administration and planning divisions lack the capabilities of arranging a number of issues in reference to citizens' quality of life(Aguilar, 2008). A study conducted in Karachi shows the poor administration and disorganized political structure was unable to control various mafias within the precincts of the constitution. Land encroachment along with misuse of authorities are very common, as a result of which, the implementation of rules regarding living standards becomes exceedingly difficult (Burke, Azam, ul Huda, \& Hamza, 2007; Azam, Burke, Nawazul-Huda, \& Miandad, 2012; Miandad, Burke, Nawaz-ul-Huda, \& Azam, 2017). Gujrat is also facing such a problem along with mismanagement of urban expansion, as well as narrow streets and solid waste management. 


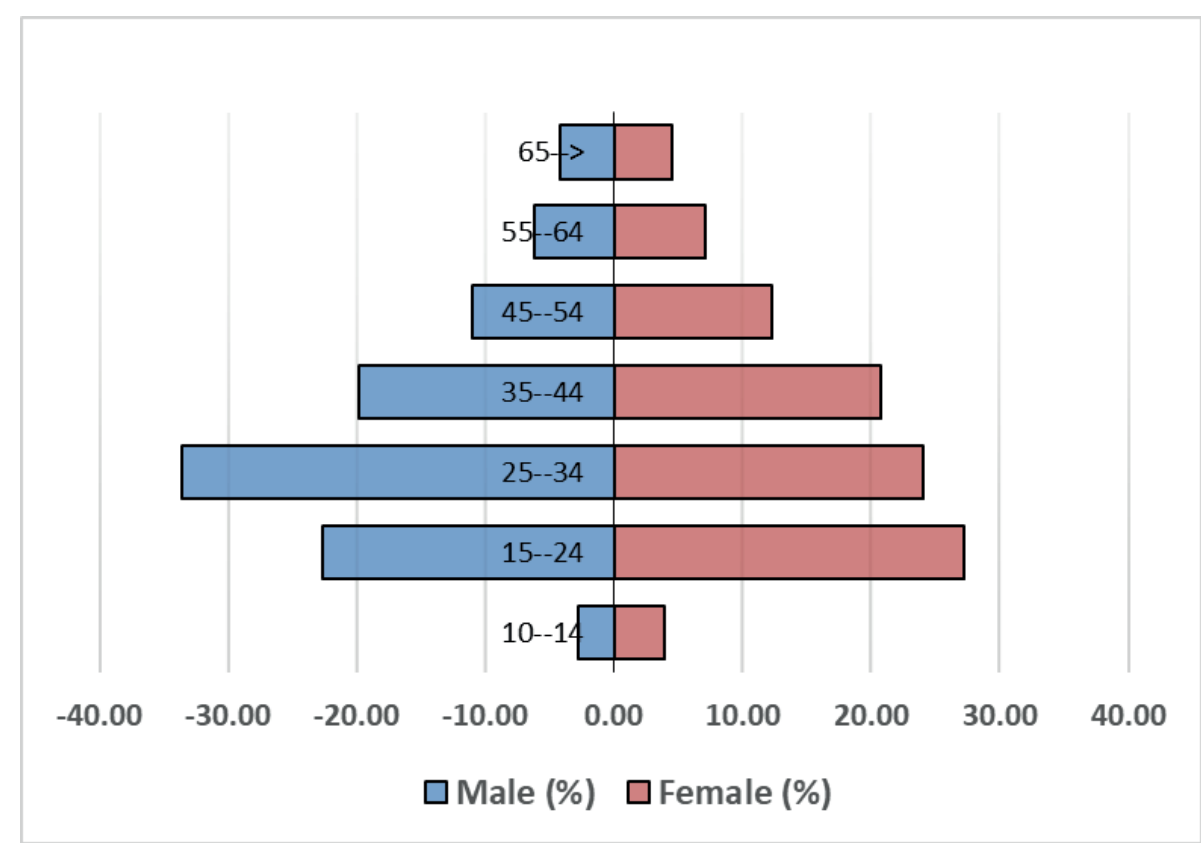

Figure 4: Age and Sex pyramid of TB patients (Data source: Author Survey).

The sex ratio of tuberculosis patients' (respondents) in different age groups is shown in Figure 4, which shows that the percentage of female patients was slightly higher than that of males, i.e., 51.33 $\%(\mathrm{~N}=156)$ and $48.66 \%(\mathrm{~N}=146)$ respectively. The salient feature of the pyramid was the highest (i.e., 27.27\%) percentage of female patients in the age group of 15-24, while that of males was the highest in the age group 25-34 (32.56\%). The lowest recorded incidence, both among males and females, was in the age bracket 10-14 (4.11 and $4.55 \%$ respectively). The reason for these age-sex differences may be attributed to the fact that not much attention has been paid to the food and health of girls in third world countries, while young boys in the age group 21-34, live under the burden of joblessness and attainment of jobs, thus becoming addicted to various destructive habits, smoking being one of them, which coupled with a deprived diet, increase the likelihood of contracting tuberculosis.

Extracted variables of Factor I have indicated causes and effects based on a rotated correlation. The patients who are eating meat once a month have shown the highest correlation among the 37 significant variables. The ecological variable, i.e., patients who have no tree in the house has the second-highest correlation (0.971) Figures $5 \& \mathbf{6}$ show the highest 9 significant variables of factor one. This indicates that there is a relationship of ecological indicators that are responsible for the spread of tuberculosis. The third highest values were found in those patients whose family was suffering from tuberculosis, and treatment is continued (0.965). Patients to total respondents of laborer have the fourth-highest values of PCA, i.e., 0.963 .

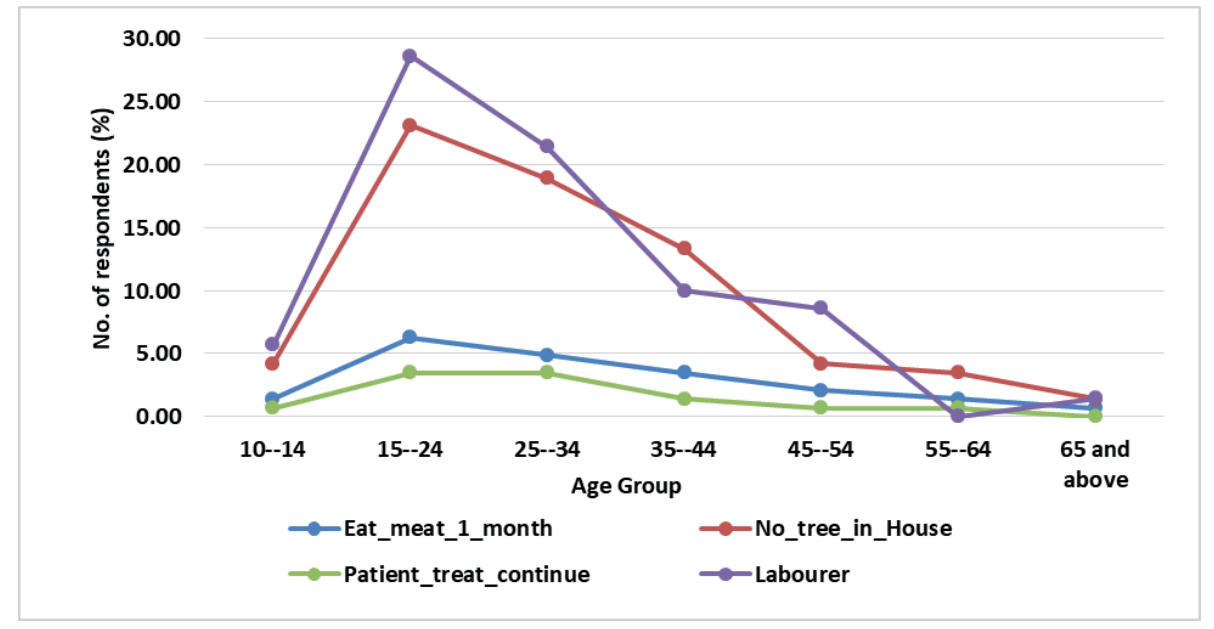

Figure 5: Significant Variables Factor 1. 


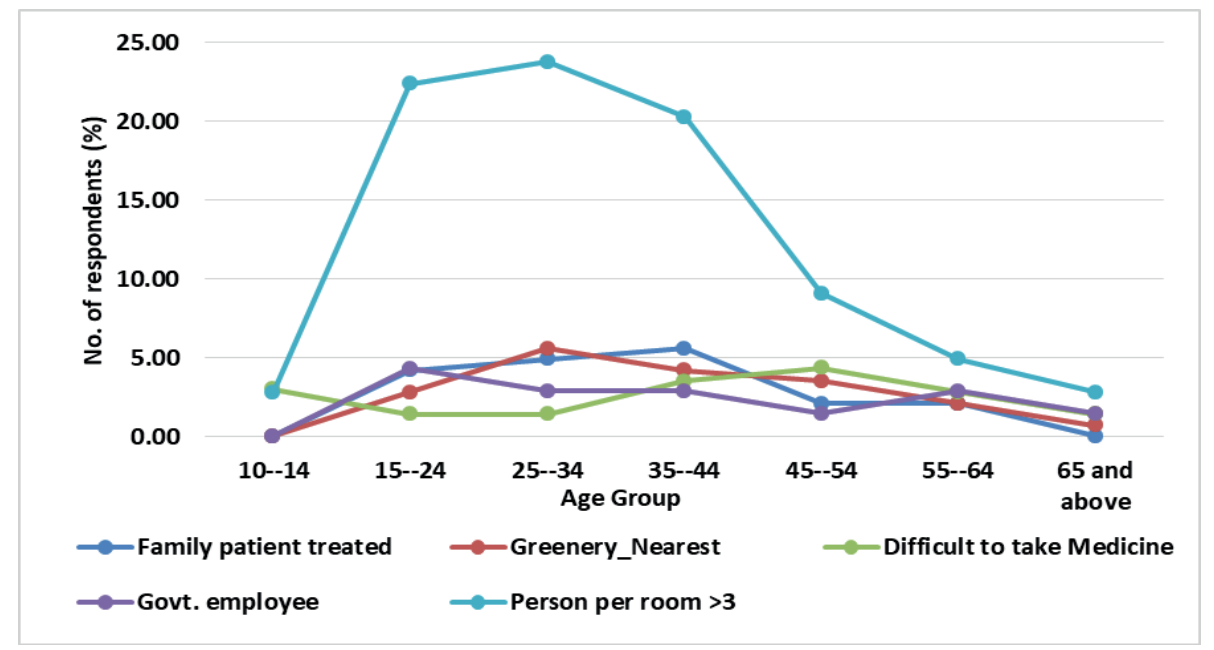

Figure 6: Factor II Socio-ecological variables.

Young unmarried girls want to be slim and they do not take breakfast due to which they suffer from malnutrition and their immune system becomes weakened, hence contract tuberculosis.

In the age group of 21-34 young unmarried males, in addition to suffering from difficulties related to joblessness and lack of care due to being bachelors, coupled with carelessness regarding nutrition, are highly exposed to conditions that endorse the contraction of TB. Spinsters and bachelors in the third world countries are fewer in comparison to married men and women because of traditional social systems, whereby marriage at a young age is common(Mathur, Greene, \& Malhotra, 2003; Lane, 2011). Therefore, the spread of contagious diseases may be attributed to poor economic conditions with their ensuing evils. As described by the Population Census Organization of Pakistan (1998), non-workers are those persons who have not been involved in any employment for even one day a week, hence are considered as dependents.

Questionnaire survey data analysis indicates that the dependent male respondents were only $25.73 \%$, and female dependents amounted to $74.27 \%$. The highest percentage of dependents among females was recorded in age group $21-30$ as $33 \%$, while among male patients it is $27 \%$ in the $60+$ age bracket. In third world countries, like Pakistan, dependency on the family system is not unfamiliar, particularly among women, children and aged members of families; as such cultural customs are deep-rooted in the traditional roots and social values of such cultures. (Zaman, Zaman, \& Stewart, 2006; Ali et al., 2011). According to NIPS (2008), more than $50 \%$ of women lack the basic education, while around $20-30$ $\%$ manages to struggle for some earnings. However, most women in Pakistan are restricted to their homes to do household tasks for their extended families, as such, being excluded from the core decision-making process.(Rabbani, Qureshi, \& Rizvi, 2008)

In Pakistan, combined family systems comprise grandparents, aunts, uncles and cousins, who share the available resources, i.e., money, food and all requirements. Traditional bondage thus severely affects the genuine and special needs of some members of the family, especially the needs of patients due to population pressure in the household and limited resources.

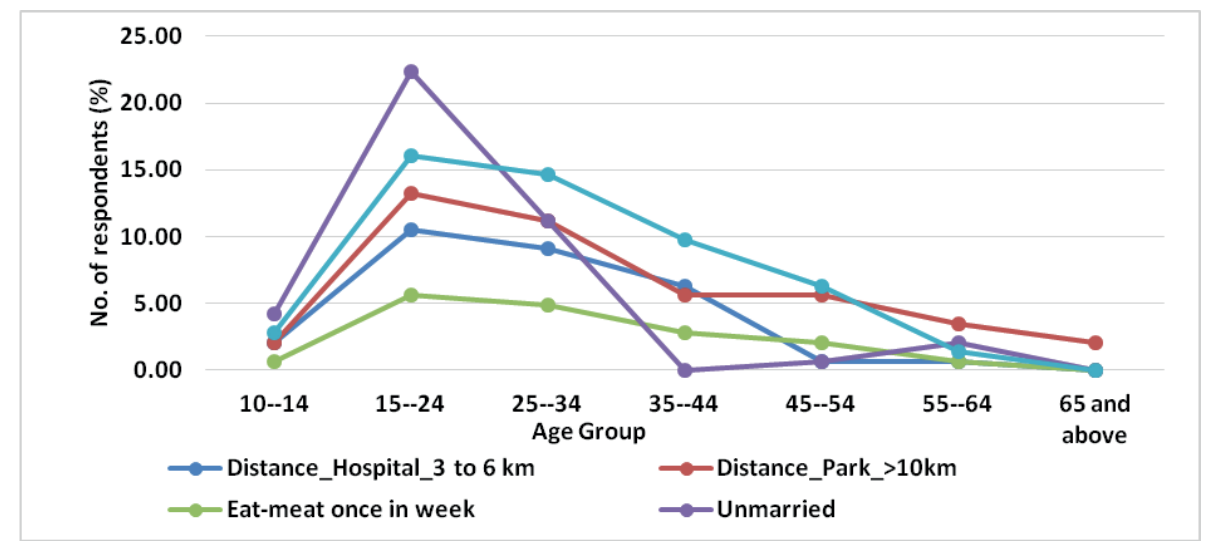

Figure 7: Significant Variable Factor 1 (b). 


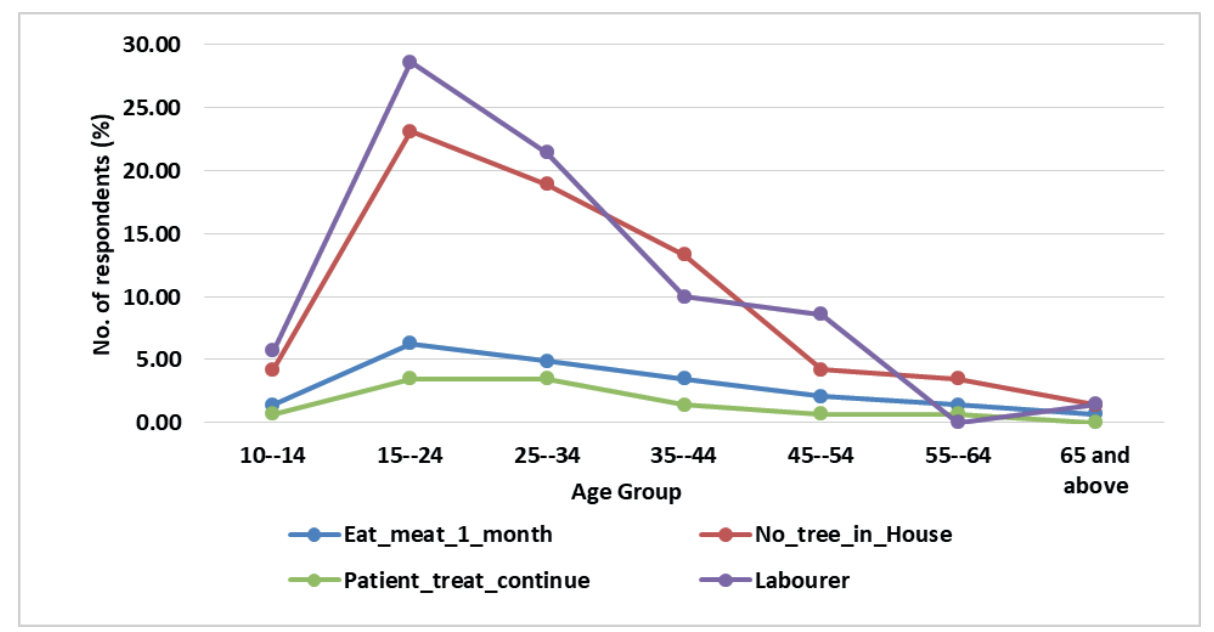

Figure 8: Significant Variables Factor 1 (a).

Figure 7 depicts the ecological conditions of tuberculosis patients, which reveals that $29.37 \%$ of the respondents live 3 to $6 \mathrm{~km}$ away from a hospital, while $43.36 \%$ respondents reside $10 \mathrm{~km}$ away from a Public Park, which indicates that public parks are not fulfilling the needs of the population in the study area. Public Parks may be helpful to promote health. The females in the age group 15-24 and males in the age group 25-34 constitute the highest percentages, i.e., 27.27 and $33.56 \%$ respectively.

This is somewhat similar to the situations of unmarried patients. Unmarried girls and boys share rooms and live closely.

This is quite similar to the situations of unmarried patients. Unmarried girls share rooms and live closely together, while males in the age group 25-34, who establish the initial working class, have to share their accommodation with co-workers or migrants, due to poor economic conditions, thus creating negative social as well as ecological conditions leading to the proliferation of infectious diseases like TB, etc. $70.54 \%$ of patients among total respondents revealed that they shared their accommodations. Unmarried patients among total respondents are high in the age group 15-34, which is the working class of the society.

Figure 8 reveals ecological factors which have high value for the respondents in the age group 15-34; these patients have no trees in the houses. Laborer patients also have the higher value in the age group of 15-34, while patients who eat meat once a month and patients who have other patients in their family have the lowest value.

Figure 9 depicts the correlation of ecological indicators, i.e., distance of respondents from greenery being more than $10 \mathrm{~km}$ and using tap water. Most patients eat food from their houses, so there was not found any significant correlation between food from bazar and from home. Patients are mostly unemployed in the age

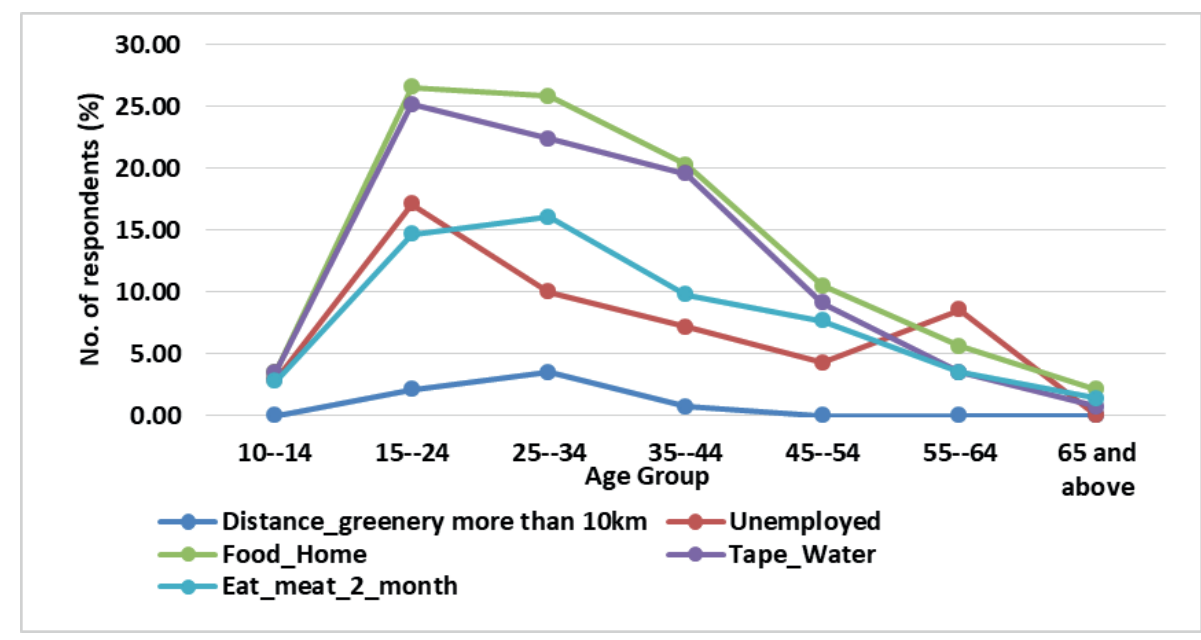

Figure 9: Ecological variables Factor 1 (a). 


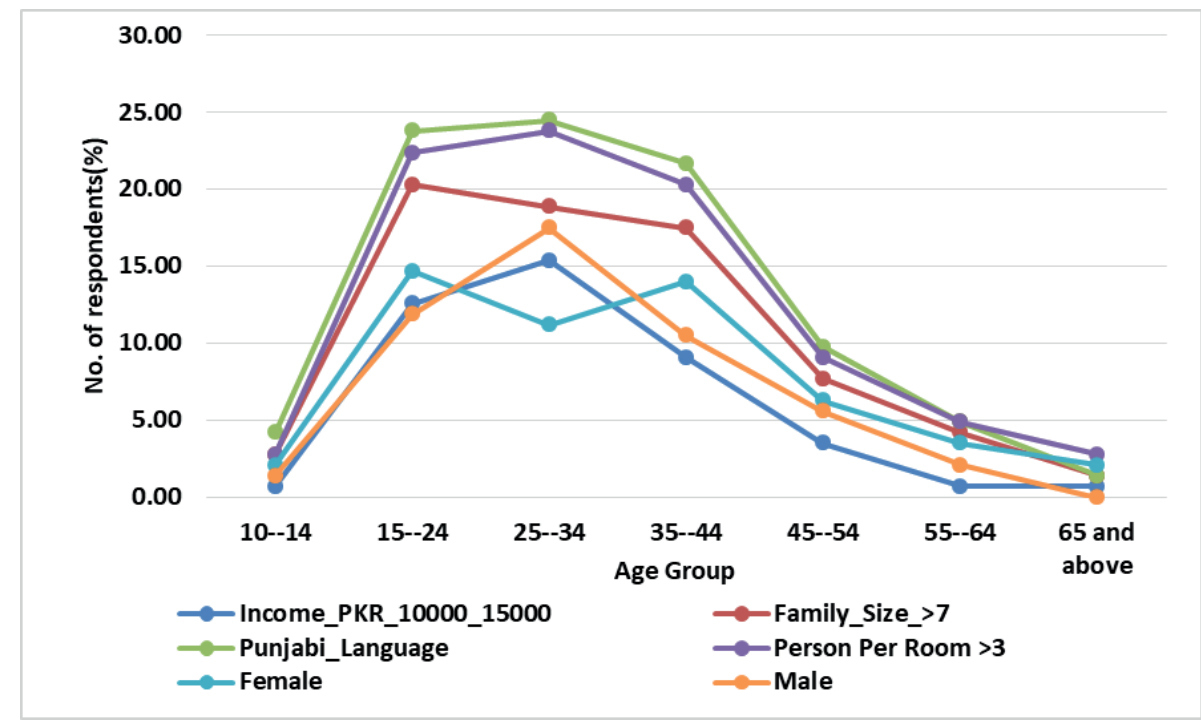

Figure 10: Socioeconomic and demographic variable Factor II.

group 15-34. Poverty also aggravates the disease because most of the patients eat meat once or twice a month. That is an alarming situation for the Govt. as well as for NGOs, which indicates the level of poverty and unhealthy food.

Figure 10 shows socioeconomic and demographic factors which reveal correlation among three types of variables, i.e., social, economic and demographic. All these factors have the highest value in the age group 15 to 45 years of age. Female and male patients have a slight difference in the age group 25-34. Males are more infected than females in the age group 25-34. Patients who are living in family with a size of more than 7 persons are more infected in the age group 15 to 35 , due to congestion in the residence. Small family size may be helpful for improving quality of life and a healthy environment.

\subsection{Factor II: Socio-economic and ecological}

The second factor explains $29.56 \%$ of the total variance of given data pertaining to TB patients. The rotated factor matrix shows that significant highest positive loading has been recorded for patients having TB patients in their family to total respondents (0.942), followed by patients having literacy level intermediate (0.934), married to total respondents (0.915), Patients having agriculture activities (0.903), Family size more than 7 person $(0.868)$ family patients treated in the patients' family (0.828), Greenery near the house (0.808), patients feel difficulties to take medicines due to distance from health care facility $(0.805)$, patients are Govt. employees (0.794), person living more than 3 in a room (0.758), monthly income 10000 to 15000 (0.753).
Eat meat once in a month (0.706), cigarette smokers who smoke more than 5 cigarettes per day (0.706), patients having graduation to total respondents $(0.680), 10 \mathrm{~km}$ distance of greenery from patients' residence (0.678), eat meat twice in a month (0.655), monthly income 16000 to 20000 (0.634),, private job (0.562), patients which are laborers $(0.551)$, factory laborer $(0.549)$, patients who have tree in house (0.533), primary education (0.524), patients smoking more than 10 cigarettes per day $(0.520)$, monthly income less than $10000(0.508)$ and patients living in a congested house (0.503).

Factor II consists of 27 variables which show positive loading. There are 13 social variables, 8 ecological variables, 6 economic variables having positive loading, which indicates the importance of variables which had not emerged in factor one, but have a high loading in factor two. Ecological factors can be identified as the risk factors of TB coupled with the socio-economic. There is an emergent need to check the level of population and ecology of the areas for eradication of the disease.

Figure 11 depicts the variables of factor II in which married patients to total respondents have the highest value in the age group 35-44, while patients having a high correlation in the family size of more than 7 persons in the age group of 15-24. Intermediate level education patients and family TB history have a similar correlation pattern while patients working in agriculture have the lowest correlation.

Patients of age group 15 to 44 have the highest value while lower in younger and older age groups. Greenery closeness, Govt. 


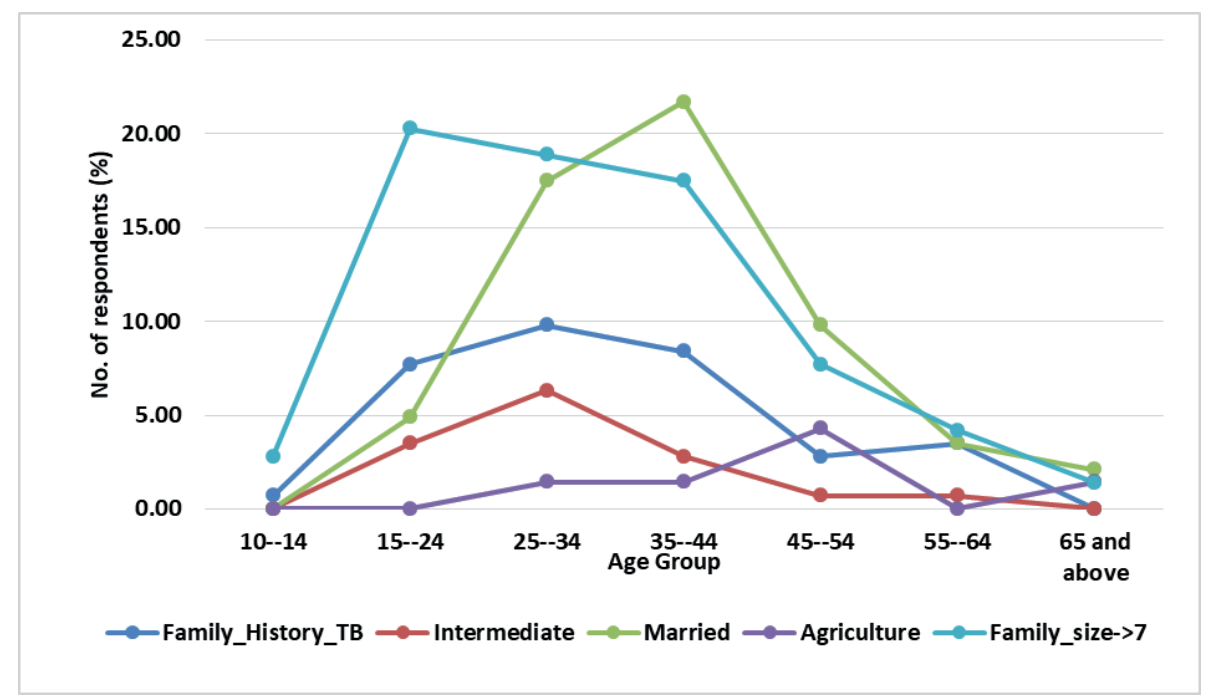

Figure 11: Significant Variables Factor II.

employee, receiving medicines, and family patients who have been treated have similar patterns among all age groups.

Factor II describes the socioeconomic variables in Figure 12. Patients in the age group 15 to 34 have the highest value, while patients who smoke more than five cigarettes per day, the distance of greenery from patients' residences, graduate patients have lower correlation among all age groups. The economic conditions of patients were severe in the study area, as tuberculosis is related to socioeconomic conditions. Escalation of TB cases was high due to a lower quality of life and socioeconomic status. It is evident from Factor I and Factor II that tuberculosis is highly correlated with ecological and socioeconomic indicators. More cases have been observed in the city which is highly urbanized, and housing congestion coupled with the living status of the societies, which is highly related to the disease condition of Gujrat city, especially tuberculosis and infectious diseases.

Socioeconomic variables of Factor II are important variables regarding the social and economic values of the population in Gujrat city. Labor to total respondents have the highest value in the age group 24-34, congested housing to total respondents has the highest value in the age group 34-45, patients who eat meat two times in a month have the highest value in the age group 1534. Other factors, like primary education, cigarette smoking, govt. employee and monthly income between 16 to 20 thousand have minor fluctuation among age groups and each other.

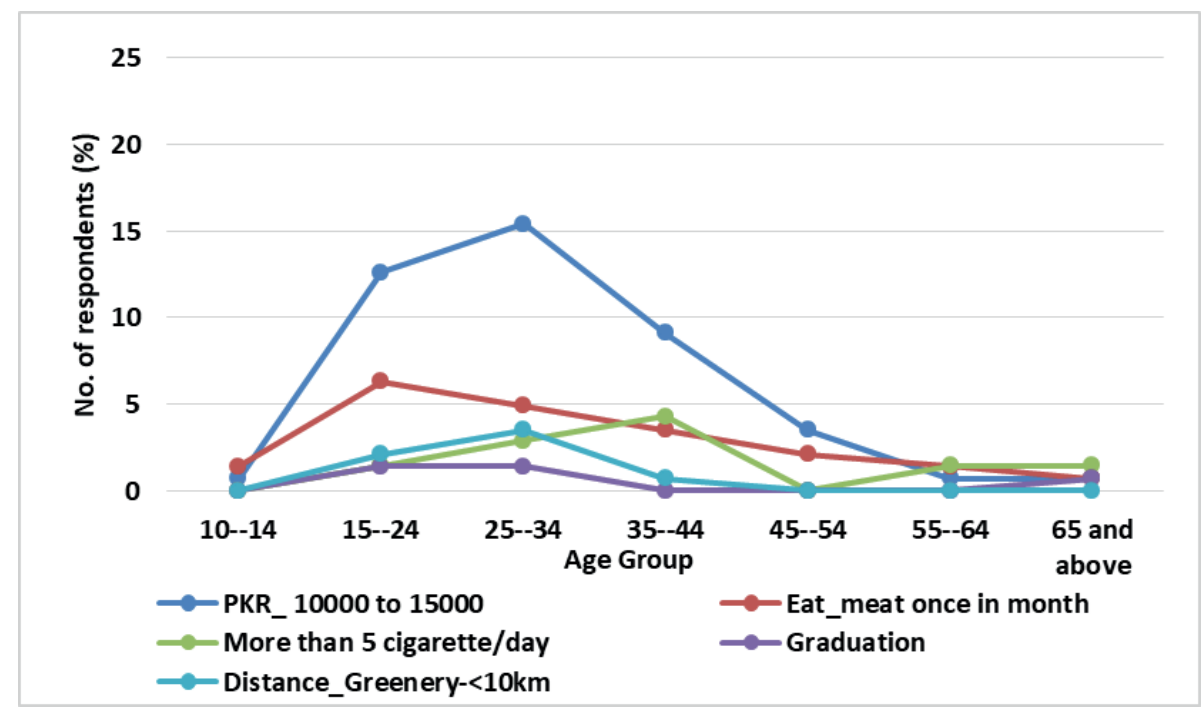

Figure 12: Factor II: Socio-economic variables (a). 


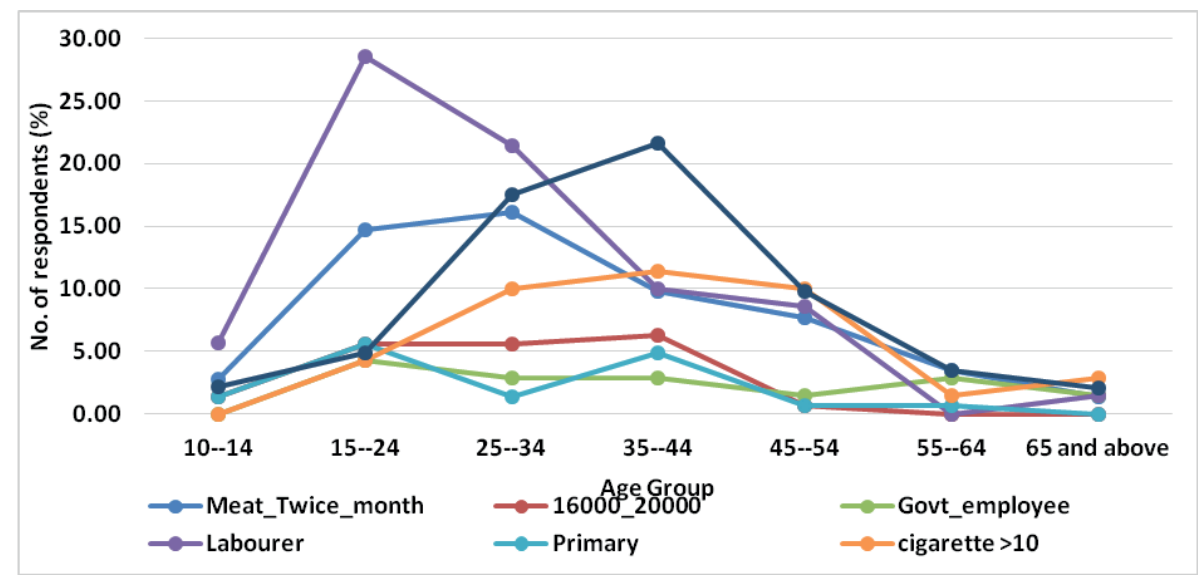

Figure 13: Factor III: Economic Cum Social and Ecological .

\subsection{Factor III: Economic cum social and ecological}

The third factor explains $9.196 \%$ of the total variance of variables pertaining to TB patients. The matrix of rotated factors shows that the significant highest positive loading has been recorded for patients living $10 \mathrm{~km}$ away from greenery to total respondents $(0.90)$, monthly income of patients which shows economic status of patients to total respondents (0.647) respondents who were employed as private to total respondents $(0.635)$ and patients who were laborers to total respondents, which is shown in Figure 13.

These variables, viewed from a general perspective, justify the entitlement of this factor as economic cum social and ecological.

Figure 13 shows that laborer patients were more in the age group 15 to 35 , and less in the upper age groups. The distance of greenery from patients' residence, monthly income of patient, and nature of the job of the respondents have a similar pattern in all age groups. Factor- III explains the social and economic nature of patients, and one variable depicts ecological variables.

\section{CONCLUSION}

Tuberculosis, a highly contagious disease has had a bad impact on human health for a long time. Pakistan, being a developing country, possesses poor health facilities. Data of Tuberculosis show the escalation of the disease within the study area. Females were more affected than males. More female cases have been observed in the age group of 14-34 than males, which is the productive age group. This age group plays a vital role in the economy of the country.
Questionnaire data were analyzed using Principal Component Analysis (PCA) with Kaiser Normalization. Three factors were extracted from the data analysis in PCA. Factor I indicates the socio-ecological cum demographic factors which explain 53.11 $\%$ of the total variance in reference to all the selected variables.

Factor I reveals that socio-ecological cum demographic factors, which are related to the urbanization and ecology of the city, appear to be categorically spreading factors of tuberculosis in Gujrat. Low-status residents are more affected than economically strong people. Restricted income and misbalanced life have emerged as prominent among tuberculosis patients. The second factor explains $29.56 \%$ of the total variance of given data pertaining to TB patients. The rotated factor matrix shows that significant highest positive loading has been recorded for patients having TB patients in their family to total respondents $(0.942)$ followed by patients having literacy level intermediate (0.934), married to total respondents (0.915). The third factor explains $9.196 \%$ of the total variance of variables pertaining to TB patients. The Third Factor is named as economic and social and ecological. Total variables having positive, i.e., 1.0 to 0.50 loading show their behavior in a certain constant approach. In the study area, all attributes that are responsible for the occurrence and spread of tuberculosis have recorded positive loadings.

Poverty, smoking, density of population, housing congestion, level of education, malnutrition, late diagnosis, accessibility to BMUs, lack of awareness, misconceptions regarding the disease and behavior of staff of basic management units have been found to be significant risk factors of TB in the current study. It can be summarized that social, economic, demographic and ecological factors along with diet and diagnosis are highly responsible for the incidence of the disease in the city. Imbalanced social 
parameters, resultant due to low, restricted incomes emerged as the most significant causative factor of TB among the patients interviewed.

The immense pressure of population, coupled with a population pyramid with a broad heavy base, tapering towards the apex, characteristic of third world countries, is not only the cause of economic pressure in the urban areas which attract migrants both from rural areas as well as smaller towns and cities to improve their quality of life, in fact to eke out a living, not only cause problems related to demographic pressure, but subsequently to ecological and other more serious problems. Economic problems lead to problems of diet and diagnosis, as financial problems not only create hurdles in acquiring treatment, but deficiency in diet further reduces any positive impact of diagnosis and treatment.

Thus, it can be concluded that all the parameters compounded in the three factors are interrelated to each other and go on in a vicious cycle perpetuating the spread of $\mathrm{TB}$, which must be controlled on a war footing in order to prevent dire consequences within the city and the country as a whole, in order to have a healthy and economically viable nation.

\section{RECOMMENDATIONS AND SUGGESTIONS FOR POLICYMAKERS}

In view of the findings related to the conditions of prevalence and spread of TB, the following suggestions have been extended, which if implemented, may go a long way in controlling the spread of the highly contagious disease:

> Implementation of policies of WHO and National TB Control Programmes.

$>$ Establishment of the National TB Research Center must be taken up on a priority basis.

$>$ The government should increase the annual budget for the health infrastructure.

$>$ BMUs should be allocated according to population and vulnerability of areas.

> Since BMUs have not been demarcated according to population, the area should be defined for each BMU.

$>$ Private clinics should refer to patients displaying symptoms of infection to BMUs for diagnosis.

> Private practitioners should be bound to maintain data related to TB patients.

> Medical stores and other drug sellers should be bound to sell the medicines as prescribed by TB specialists and make sure the registration of patients.

$>$ Awareness among patients regarding the disease and its preventive and curative measures must be promoted.

$>$ Awareness campaigns should be ensured through signboards, electronic and print media.

$>$ Paramedical and other related staff should be trained and their knowledge regarding awareness about TB treatment and precautionary measures should be enhanced.

$>$ Symptoms and precautionary measures regarding the disease should be included in the curriculum of primary schools.

$>$ Improvement in the attitude of physicians towards patients is essential since patients complained about the negligent attitude of BMU staff.

$>$ The polite behavior of DOTS personnel towards patients must be ensured.

$>$ Factors identified with reference to TB in the present research can be covered by implementing policies such as improvement of literacy rate, improvement of health facilities, provision of urban facilities according to its status, controlling the expansion of kacchi abadies, screening and resettlement of IDPs (internally displaced persons) and flood victims along with control of population explosion.

$>$ Record keeping of case management practices including diagnosis and treatment outcomes were found to be inadequate. Development and implementation of standardized operational tools and a regular monitoring system are required to improve the performance and quality of services regarding TB.

Encouragement of research projects regarding TB.

Improvement of quality of life is a dominant factor among all factors, which needs to be improved by making appropriate reforms in the economy of the country.

Acknowledgment: Authors are thankful to the Higher Education Commission of Pakistan for funding, Principal Nawaz Sharif Medical College and MS Aziz Bhatti Shaheed Hospital for the provision of relevant data and support during the survey. Authors are also thankful to blind reviewers and language editor of the journal.

Grant Support: The study was funded by Higher Education Commission of Pakistan
Abbreviations and acronyms:
BMU: Basic Management Unit
TB: Tuberculosis
NTP: National TB Control Program Pakistan
UCs: Union councils (i.e. smallest administrative unit)
WHO: World Health Organization
PPs: Private Providers 


\section{REFERENCES}

Aguilar, A. G. (2008). Peri-urbanization, illegal settlements and environmental impact in Mexico City. Cities, 25(3), 133-145.

Ali, T. S., Krantz, G., Gul, R., Asad, N., Johansson, E., \& Mogren, I. (2011). Gender roles and their influence on life prospects for women in urban Karachi, Pak0istan: a qualitative study. Global health action, 4(1), 7448.

Antczak, E. (2016). Environmental health-global and urban aspects „EkoMiasto\# Spoleczeństwo. Zrównoważony, inteligentny $i$ partycypacyjny rozwój miasta”, red. A. Nowakowska, Z. Przygodzki, A. Rzeńca, Wydawnictwo Uniwersytetu Łódzkiego, Łódź 2016; : Wydawnictwo Uniwersytetu Łódzkiego.

Antrop, M., \& Van Eetvelde, V. (2000). Holistic aspects of suburban landscapes: visual image interpretation and landscape metrics. Landscape and urban planning, 50(1-3), 43-58.

Azam, M., Burke, F., Nawaz-ul-Huda, S., \& Miandad, M. (2012). Open Green Spaces-Shah Faisal Town, Karachi, Pakistan: A Temporal Perspective. Karachi University Journal of Science, 40, 5-11.

Burke, F., Azam, M., ul Huda, S. N., \& Hamza, S. (2007). Open Green Spaces-Asset or Liability-Case Study of North Nazimabad TownKarachi. Karachi University Journal of Science, 35, 23-30.

Byers, V. (2016). Democratic Governance and Health: Hospitals, Politics, and Health in New Zealand: Duke University Press.

Cameron, C. M., Nazar, J. C., Ehrlich, C., Kendall, E., Crompton, D., Liddy, A. M., \& Kisely, S. (2018). General practitioner management of chronic diseases in adults with severe mental illness: a community intervention trial. Australian Health Review, 41(6), 665-671.

Cresswell, K., \& Sheikh, A. (2013). Organizational issues in the implementation and adoption of health information technology innovations: an interpretative review. International journal of medical informatics, 82(5), e73-e86.

Creswell, J. W., \& Creswell, J. D. (2017). Research design: Qualitative, quantitative, and mixed methods approaches: Sage publications.

De Muynck, A., Siddiqi, S., Ghaffar, A., \& Sadiq, H. (2001). Tuberculosis control in Pakistan: critical analysis of its implementation. J Pak Med Assoc, 51(1), 41-47.

Deneulin, S., \& Alkire, S. (2009). A normative framework for development An introduction to the human development and capability approach (pp. 25-35): Routledge.

Dunteman, G. (1989). Main components analysis (No. 69): Sage.

Eisenberg, J. N., Desai, M. A., Levy, K., Bates, S. J., Liang, S., Naumoff, K., \& Scott, J. C. (2007). Environmental determinants of infectious disease: a framework for tracking causal links and guiding public health research. Environmental Health Perspectives, 115(8), 12161223.

Farchi, S., Mantovani, J., Borgia, P., \& Giorgi Rossi, P. (2008). Tuberculosis incidence, hospitalisation prevalence and mortality in Lazio, Italy, 1997-2003. The International Journal of Tuberculosis and Lung Disease, 12(2), 193-198.
Fatima, R., Harris, R., Enarson, D., Hinderaker, S., Qadeer, E., Ali, K., \& Bassilli, A. (2014). Estimating tuberculosis burden and case detection in Pakistan. The International Journal of Tuberculosis and Lung Disease, 18(1), 55-60.

Gatrell, A., \& Loytonen, M. (1998). GIS and health. GISDATA VI: London: Taylor \& Francis.

Hawthorne, G., Richardson, J., \& Osborne, R. (1999). The Assessment of Quality of Life (AQoL) instrument: a psychometric measure of health-related quality of life. Quality of Life Research, 8(3), 209-224.

Hossain, S., Quaiyum, M. A., Zaman, K., Banu, S., Husain, M. A., Islam, M. A., Cooreman, E., Borgdorff, M., Lönnroth, K., \& Salim, A. H. (2012). Socio economic position in TB prevalence and access to services: results from a population prevalence survey and a facilitybased survey in Bangladesh. PloS one, 7(9), e44980.

Keall, M. D., Crane, J., Baker, M. G., Wickens, K., Howden-Chapman, P., \& Cunningham, M. (2012). A measure for quantifying the impact of housing quality on respiratory health: a cross-sectional study. Environmental Health, 11(1), 33.

Khan, M. A., Nazir, S., Tahir, A. H., Khan, I., Abbas, T., \& Younus, M. (2007). Study on human tuberculosis with reference to sociodemographic factors. Punjab Univ J Zool, 22(1-2), 57-61.

Lane, S. (2011). Stealing innocence: Child marriage and gender inequality in Pakistan. Plan Finland \& Abo Akademi University, Finland, 1-44. Lienhardt, C., Fielding, K., Sillah, J., Bah, B., Gustafson, P., Warndorff, D., Palayew, M., Lisse, I., Donkor, S., \& Diallo, S. (2005). Investigation of the risk factors for tuberculosis: a case-control study in three countries in West Africa. International journal of epidemiology, 34(4), 914-923.

Lopez-Carr, D., \& Ervin, D. (2017). POPULATION-HEALTHENVIRONMENT (PHE) SYNERGIES? EVIDENCE FROM USAIDSPONSORED PROGRAMS IN AFRICAN AND ASIAN CORE CONSERVATION AREAS. European Journal of Geography, 8(3), 92-108.

Mangtani, P., Jolley, D. J., Watson, J. M., \& Rodrigues, L. C. (1995). Socioeconomic deprivation and notification rates for tuberculosis in London during 1982-91. BMj, 310(6985), 963-966.

Mankin, E. (2003). Principal Components Analysis: A How-To Manual for R. Desde http://psych. colorado. edu/wiki/lib/exe/fetch. php.

Mathur, S., Greene, M., \& Malhotra, A. (2003). Too young to wed: the lives, rights and health of young married girls.

Miandad, M., Burke, F., Nawaz-ul-Huda, S., \& Azam, M. (2017). Tuberculosis incidence in Karachi: a spatio-temporal analysis. Geografia-Malaysian Journal of Society and Space, 10(5).

Miandad, M., Burke, F., Nawaz-ul-Huda, S., Ghazi, S., \& Azam, M. (2015). Lingual Distribution of Tuberculosis Patients in Karachi-A Demographic Analysis. Journal of Basic and Applied Sciences, 11, 74-80.

Miandad, M., Burke, F., Ul-Huda, S. N., \& Azam, M. (2015). Geodemographic Analysis of Tuberculosis Patients in Karachi. Human Geographies-Journal of Studies and Research in Human Geography, $9(2)$. 
Miandad, M., Nawaz-ul-Huda, S., Burke, F., Hamza, S., \& Azam, M. (2016). Educational status and awareness among tuberculosis patients of Karachi. JPMA. The Journal of the Pakistan Medical Association, 66(3), 265-269.

Middelkoop, K., Bekker, L.-G., Morrow, C., Lee, N., \& Wood, R. (2014). Decreasing household contribution to TB transmission with age: a retrospective geographic analysis of young people in a South African township. BMC infectious diseases, 14(1), 221.

Obermeyer, Z., Abbott-Klafter, J., \& Murray, C. J. (2008). Has the DOTS strategy improved case finding or treatment success? An empirical assessment. PloS one, 3(3), e1721.

Pauleit, S., Ennos, R., \& Golding, Y. (2005). Modeling the environmental impacts of urban land use and land cover change - a study in Merseyside, UK. Landscape and urban planning, 71(2-4), 295-310.

Pearson, K. (1901). Principal components analysis. The London, Edinburgh, and Dublin Philosophical Magazine and Journal of Science, 6(2), 559.

Qadeer, E., Fatima, R., Yaqoob, A., Tahseen, S., Haq, M. U., Ghafoor, A., Asif, M., Straetemans, M., \& Tiemersma, E. W. (2016). Population based national tuberculosis prevalence survey among adults $(>15$ years) in Pakistan, 2010-2011. PloS one, 11(2), e0148293.

Rabbani, F., Qureshi, F., \& Rizvi, N. (2008). Perspectives on domestic violence: case study from Karachi, Pakistan.

Rees, D., Murray, J., Nelson, G., \& Sonnenberg, P. (2010). Oscillating migration and the epidemics of silicosis, tuberculosis, and HIV infection in South African gold miners. American journal of industrial medicine, 53(4), 398-404.

Shetty, N., Shemko, M., Vaz, M., \& D'souza, G. (2006). An epidemiological evaluation of risk factors for tuberculosis in South India: a matched case control study. The International Journal of Tuberculosis and Lung Disease, 10(1), 80-86.

Silverman, D. (2013). Doing qualitative research: A practical handbook: SAGE Publications Limited.
Tavakol, M., \& Sandars, J. (2014). Quantitative and qualitative methods in medical education research: AMEE Guide No 90: Part II. Medical teacher, 36(10), 838-848.

Tiberi, S., Petersen, E., Maeurer, M., Ntoumi, F., Yeboa-Manu, D., Mwaba, P., Vilaplana, C., Dar, O., Bates, M., \& Corrah, T. (2018). Taking forward the Stop TB Partnership and World Health Organization Joint Theme for World TB Day March 24th 2018 - "Wanted: Leaders for a TB-Free World. You can make history. End TB". International Journal of Infectious Diseases, 68, 122-124.

Turkington, C., \& Ashby, B. (2007). The encyclopedia of infectious diseases: Infobase Publishing.

Wanyeki, I., Olson, S., Brassard, P., Menzies, D., Ross, N., Behr, M., \& Schwartzman, K. (2006). Dwellings, crowding, and tuberculosis in Montreal. Social science \& medicine, 63(2), 501-511.

Williams, B., Onsman, A., \& Brown, T. (2010). Exploratory factor analysis: A five-step guide for novices. Australasian Journal of Paramedicine, $8(3)$.

World Health Organization, W. (2006). WHO REPORT 2006: global tuberculosis control: surveillance, planning, financing $W H O$ report 2006: global tuberculosis control: surveillance, planning, financing.

World Health Organization, W. (2010). Global tuberculosis control: WHO report 2010: World Health Organization.

World Health Organization, W. (2019). The WHO global task force on TB impact measurement: World Health Organization.

Zaman, R. M., Zaman, T. R., \& Stewart, S. M. (2006). Pakistan: culture, community, and filial obligations in a Muslim society. Paper presented at the Families across cultures: A 30 nation psychological study.

Zumla, A., George, A., Sharma, V., Herbert, R. H. N., Oxley, A., \& Oliver, M. (2015). The WHO 2014 global tuberculosis report-further to go. The Lancet Global Health, 3(1), e10-e12. 


\section{Appendix A: Rotated component matrix of PCA}

\begin{tabular}{|c|c|c|c|c|c|}
\hline \multicolumn{6}{|c|}{ Rotated Component Matrix } \\
\hline \multicolumn{2}{|l|}{ Factor 1} & \multicolumn{2}{|c|}{ Factor 2} & \multicolumn{2}{|l|}{ Factor 3} \\
\hline Eat_meat_1m & .973 & Family_TB & .942 & Dist_Greenery-\&gt; $10 \mathrm{~km}$ & .904 \\
\hline No_tree_House & .971 & Inter & .934 & 21000_30000 & .647 \\
\hline F_P_Trt_cont & .965 & Married & .915 & Privatejob & .635 \\
\hline Labourer & .963 & Agriculture & .903 & Labourer & .631 \\
\hline Dist-Hosp_3-6 & .957 & Fmly-sz\&gt;7 & .868 & Female & .495 \\
\hline Dist_Park_\&gt;10km & .953 & F_P_Trted & .828 & Dist_Park_\&gt; $10 \mathrm{~km}$ & .490 \\
\hline eat-meat_1w & .944 & Greenery_Nearest & .808 & F_P_Trted & .480 \\
\hline Unmarried & .942 & Yes_Difficult-Med & .805 & eat-meat_2w & .441 \\
\hline Matric & .924 & Govt.job & .794 & Dist_Park_\&lt;5 & .371 \\
\hline Dist_Greenery-\&gt; $10 \mathrm{~km}$ & .913 & PPR\&gt;3 & .758 & PPR\&gt;3 & .351 \\
\hline Unemployed & .907 & 10000_15000 & .753 & Fmly-sz\&gt;7 & .346 \\
\hline Food_Home & .894 & Eat_meat_1m & .706 & H_Congested & .299 \\
\hline Eat_meat_2m & .884 & \&It;5_cigaratte & .706 & Dist_Greenery-\&lt;10km & .245 \\
\hline 10000_15000 & .878 & Graduation & .680 & 16000_20000 & .225 \\
\hline Fmly-sz\&gt;7 & .869 & $\begin{array}{l}\text { Dist_Greenery- } \\
\& 1 \mathrm{t} ; 10 \mathrm{~km}\end{array}$ & .678 & No_tree_House & .220 \\
\hline Punjabi & .851 & Eat_meat_2m & .655 & Male & .219 \\
\hline PPR\&gt;3 & .847 & 16000_20000 & .634 & Unmarried & .189 \\
\hline Dist_Greenery-\&lt;10km & .845 & Privatejob & .562 & Family_TB & .166 \\
\hline Female & .809 & Labourer & .551 & Inter & .165 \\
\hline Male & .807 & Factory_labour & .549 & Eat_meat_2m & .162 \\
\hline Graduation & .797 & Yes_Tree_House & .533 & Graduation & .159 \\
\hline 16000_20000 & .796 & Primary & .524 & Married & .138 \\
\hline Inter & .795 & 10\&gt;_cigaratte & .520 & Yes_Tree_House & .131 \\
\hline Kashmiri & .793 & \&lt; _10000 & .508 & Kashmiri & .112 \\
\hline Family_TB & .777 & H_Congested & .503 & Matric & .107 \\
\hline Dist_Hosp6-10 & .776 & Urdu & .495 & Agriculture & .106 \\
\hline Govt.job & .750 & Unemployed & .444 & Dist-Hosp_3-6 & .075 \\
\hline Urdu & .725 & F_P_Trt_cont & .442 & Primary & .072 \\
\hline Primary & .717 & eat-meat_2w & .405 & F_P_Trt_cont & .057 \\
\hline Dist_Park_\&lt;10km & .694 & Unmarried & .394 & Dist_Greenery-\&It;5km & .054 \\
\hline Dist_Greenery-\&lt;5km & .690 & Dist_Greenery-\&lt;5km & .338 & \&lt;5_cigaratte & .053 \\
\hline eat-meat_2w & .683 & Dist_Park_\&lt;10km & .290 & 10\&gt;_cigaratte & .035 \\
\hline Dist_Park_\&lt;5 & .682 & Dist-Hosp_3-6 & .268 & Food_Home & .031 \\
\hline F_P_Trted & .674 & Food_Bazaar & .240 & Fmly_sz_\&lt;4 & .029 \\
\hline Dist_Hosp\&gt;10 & .665 & Punjabi & .226 & Punjabi & .008 \\
\hline Fmly_sz_\&lt;4 & .572 & Food_Home & .225 & Eat_meat_1m & -.001 \\
\hline Food_Bazaar & .526 & eat-meat_1w & .218 & Urdu & -.019 \\
\hline Privatejob & .504 & Female & .178 & Dist_Hosp6-10 & -.025 \\
\hline Greenery_Nearest & .493 & Kashmiri & .149 & Unemployed & -.025 \\
\hline Yes_Tree_House & .326 & No_tree_House & .120 & eat-meat_1w & -.026 \\
\hline \&lt;5_cigaratte & .313 & $\begin{array}{l}\text { Dist_Greenery- } \\
\text { \&gt;10km }\end{array}$ & .119 & \&It; _10000 & -.062 \\
\hline Married & .269 & Fmly_sz_\&lt;4 & .088 & Food_Bazaar & -.123 \\
\hline H_Congested & .258 & Dist_Park_\&gt;10km & .077 & Dist_Hosp\&gt; 10 & -.137 \\
\hline Factory_labour & .240 & Dist_Hosp\&gt;10 & .020 & Govt.job & -.139 \\
\hline 10\&gt;_cigaratte & .219 & 21000_30000 & -.014 & Factory_labour & -.202 \\
\hline Illiterate & .073 & Matric & -.139 & 10000_15000 & -.249 \\
\hline 21000_30000 & -.153 & Dist_Park_\&It;5 & -.190 & Greenery_Nearest & -.281 \\
\hline Yes_Difficult-Med & -.166 & Male & -.227 & Yes_Difficult-Med & -.373 \\
\hline \&lt; _10000 & -.253 & Dist_Hosp6-10 & -.318 & Illiterate & -.449 \\
\hline Agriculture & -.326 & Illiterate & -.328 & Dist_Park_\&lt;10km & -.599 \\
\hline
\end{tabular}




\section{Appendix B: Questionnaire}

\section{Assessment of risk factors associated with spread of tuberculosis in Gujrat city \\ Pakistan \\ Department of Geography, University of Gujrat}

Correspondent ID

Code No $\mathrm{UC} /$ town

\begin{tabular}{|c|c|c|c|c|c|c|c|c|c|c|c|}
\hline \multicolumn{5}{|c|}{ ID of Respondent: } & \multicolumn{7}{|c|}{ esidential Address: } \\
\hline Age: & $0-10$ & \multicolumn{2}{|c|}{$11-20$} & $21-30$ & \multicolumn{2}{|c|}{$31-40$} & $41-$ & & \multicolumn{2}{|c|}{$51-60$} & $60+$ \\
\hline Gender: & Male & \multicolumn{3}{|c|}{ Female } & \multicolumn{3}{|c|}{ Marital status: } & & ried & \multicolumn{2}{|c|}{ Unmarried } \\
\hline \multirow[t]{2}{*}{ Profession: } & \multicolumn{2}{|c|}{ Unemployed } & \multicolumn{2}{|c|}{ Housewife } & Lab & & \multicolumn{3}{|c|}{ Domestic servant } & \multicolumn{2}{|c|}{ Private Job } \\
\hline & \multicolumn{3}{|c|}{ Govt. Employee } & Personal & \multicolumn{3}{|c|}{ Teaching } & \multicolumn{2}{|c|}{ Medical } & \multicolumn{2}{|c|}{ I.T Industry } \\
\hline \multirow{3}{*}{ Education: } & \multicolumn{5}{|c|}{ Eactory Worker } & \multirow{2}{*}{\multicolumn{3}{|c|}{ Middle }} & \multirow{2}{*}{\multicolumn{3}{|c|}{ Matriculate }} \\
\hline & \multicolumn{2}{|c|}{ Illiterate } & \multicolumn{3}{|c|}{ Primary } & & & & & & \\
\hline & Interm & & & aduate & & \multicolumn{3}{|c|}{ Master } & \multicolumn{3}{|c|}{ M.Phil/Ph.D } \\
\hline \multirow{3}{*}{$\begin{array}{l}\text { Monthly in } \\
\text { Language: }\end{array}$} & ome $(\mathrm{P}$ & \multicolumn{2}{|c|}{$<8000$} & \multicolumn{2}{|c|}{$<16000$} & \multicolumn{3}{|c|}{$<24000$} & \multicolumn{2}{|c|}{$>24000$} & \\
\hline & \multicolumn{2}{|c|}{ Punjabi } & \multicolumn{3}{|c|}{ Urdu } & \multicolumn{3}{|c|}{ Pashto } & \multicolumn{3}{|c|}{ Balochi } \\
\hline & \multicolumn{2}{|c|}{ Seraiki } & \multicolumn{3}{|c|}{ Hindko } & \multicolumn{3}{|c|}{ Kashmiri } & \multicolumn{3}{|c|}{ Afghani } \\
\hline
\end{tabular}

Family status: \begin{tabular}{|l|l|}
\hline Nucleated & Joint \\
\cline { 2 - 2 }
\end{tabular}

Place of birth:

Duration of residence at current address:

Name of place of previous residence (if any):

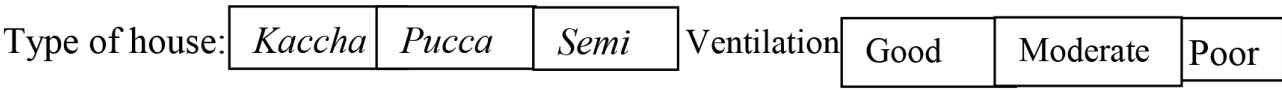
\begin{tabular}{l|l|l|}
\hline Penetration of sunlight: & Yes & No \\
\hline
\end{tabular}

Number of family members: \begin{tabular}{|l|l|l|l|l|}
\hline 2 & 3 & 4 & 5 & \\
\hline
\end{tabular} No of rooms: \begin{tabular}{|l|l|l|l|l|}
\hline 1 & 2 & 3 & 4 & \\
\hline
\end{tabular}

\begin{tabular}{l|l|l|l|l|} 
Source of drinking water: & Tap & Boring & Well & Mineral Water \\
\cline { 2 - 5 }
\end{tabular}

\begin{tabular}{ll|l} 
Condition of residential area: & Along wide street & Along narrow lane \\
\cline { 2 - 3 }
\end{tabular}

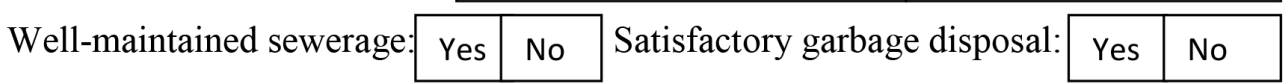

Presence of greenery in house: \begin{tabular}{l|l} 
Yes & No \\
\hline
\end{tabular}

Availability of food:

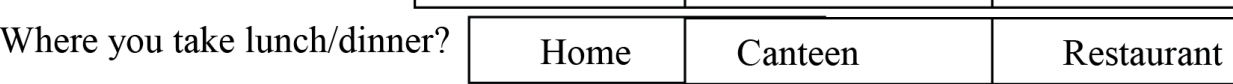




\section{Appendix B: Questionnaire}

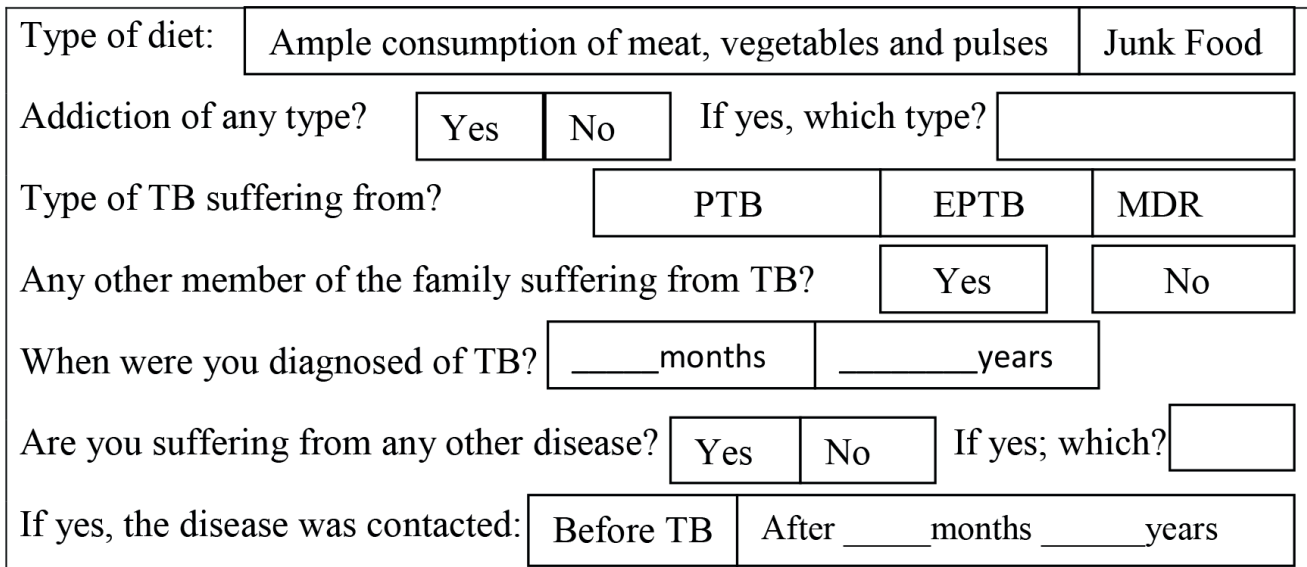

For preventing spread of TB, the patient should live in:

\begin{tabular}{|l|l|l|}
\hline Separate Room & Combined & Do not know \\
\hline
\end{tabular}

\begin{tabular}{|l|l|l|}
\cline { 2 - 2 } Have you been inoculated with BCG? & Yes & No \\
\hline
\end{tabular}

Are you registered at BMU?

\begin{tabular}{|c|c|c|}
\hline Yes & No & Do not know \\
\hline
\end{tabular}

\begin{tabular}{ll|l|l|}
\cline { 3 - 3 } Satisfaction with present treatment: & Yes & No & Any problem: \\
\cline { 2 - 3 } &
\end{tabular}

Suggest some measures for reducing spread of tuberculosis:

Note. All information will be used for research purpose only. 